University of Nebraska - Lincoln

DigitalCommons@University of Nebraska - Lincoln

Journal for the Advancement of Developing

Economies

Economics Department

2012

\title{
Supply Response, Exchange Rate and Domestic Price in Nigeria
}

Emmanuel C. Ani

Federal University, Wukari, Nigeria

Samson Adeniyi Aladejare

Federal University, Wukari, Nigeria

Follow this and additional works at: https://digitalcommons.unl.edu/jade

Part of the Econometrics Commons, Growth and Development Commons, International Economics

Commons, Political Economy Commons, Public Economics Commons, and the Regional Economics

Commons

Ani, Emmanuel C. and Aladejare, Samson Adeniyi, "Supply Response, Exchange Rate and Domestic Price in Nigeria" (2012). Journal for the Advancement of Developing Economies. 18.

https://digitalcommons.unl.edu/jade/18

This Article is brought to you for free and open access by the Economics Department at DigitalCommons@University of Nebraska - Lincoln. It has been accepted for inclusion in Journal for the Advancement of Developing Economies by an authorized administrator of DigitalCommons@University of Nebraska - Lincoln. 


\title{
Supply Response, Exchange Rate and Domestic Price in Nigeria
}

\author{
Emmanuel C. Ani, Samson A. Aladejare \\ Federal University, Wukari, Nigeria
}

\begin{abstract}
The purpose of this paper is to empirically investigate the impact of exchange rate and domestic price on export trade in Nigeria. Firstly, based on the literature review and findings of the study in the area, the paper aligned itself within the premise of the traditionalist view which concludes that non-oil export trade in Nigeria is predicated by currency depreciation via lower export prices. Secondly, the introduction of domestic prices, alongside naira rate of exchange as major determinants of non-oil exports in Nigeria, has the implication of showing that currency devaluation could be used to improve the balance of payment position of the country. We therefore recommend policy measures from the monetary authorities in the country that would stabilize the foreign exchange market and the exchange rate. Caution on the part of the government is also recommended when adopting trade policies to ensure Nigeria does not end up with unfavorable terms of trade and balance of payments with trading partner countries.
\end{abstract}

\section{INTRODUCTION}

Research related to exchange rate management will remain of interest to economists, especially in developing countries, despite a relatively large amount of literature in the area. This is mainly because the exchange rate in whatever conceptualization is not only an important relative price that connects domestic and world markets for goods and assets, but also serves as an indication of how competitive a country's exchange power is vis-à-vis the rest of the market-based world. The exchange additionally serves as an anchor which supports sustainable internal and external macroeconomic balances over the medium to long term. There is, however, no simple answer to what determines the equilibrium exchange rate and estimating equilibrium exchange rates, making the degree of exchange rate misalignment as one of the most challenging empirical problems in open-economy macroeconomics (Williamson, 1994). The core difficulty is that the equilibrium value of the exchange rate is not observable.

While the exchange rate misalignment refers to a situation in which a country's actual exchange rate deviates from such an unobservable equilibrium. An exchange rate is said to be "undervalued" when it depreciates more than its equilibrium and said to be "overvalued" when it appreciates more than its equilibrium. The issue is, unless the "equilibrium" is unambiguously specified, the concept of exchange rate misalignment remains subjective. According to Chang and David (2005), the problem of subjectivity is because exchange rate equilibrium or misalignment is measured over various time horizons. Notwithstanding, Edwards (1989) states that the equilibrium real exchange rate (RER) holds when given sustainable values for other relevant variables such as terms of trade, capital and aid flows, and technology, the economy achieves both internal and external equilibrium. 
Economies with fixed or less than flexible nominal exchange rate regimes without foresight and suitable policies on the part of the government are subject to real exchange rate misalignment that may have disastrous consequences. Accordingly, a successful development strategy for a less developed economy or emerging market economy such as Nigeria should include efforts to maintain the real exchange rate at or near the 'equilibrium' level regardless of exchange rate regime. This is because there is a growing agreement in the literature that prolonged and substantial exchange rate misalignment can generate severe macroeconomic disequilibria and the correction of external balance will require both exchange rate devaluation and demand management policies. Therefore, an increase in exchange rate volatility leads to uncertainty, which might have a negative impact on trade flows, or lead to the aversion of firms to engage in risky trade ventures due to the economic logic underpinning (Anderton 2001). Baldwin, Skudelny and Taglioni (2005) discovered that the effect of exchange rate uncertainty on trade in the European Union (EU) countries is negative; trade increases as volatility falls and grows progressively larger as volatility approaches zero. While numerous studies have been conducted on the extent of naira exchange rate and its misalignment in Nigeria $^{1}$, assessment of the impact of exchange rate volatility on the supply response for Nigerian non-oil exports have in the recent past been given less consideration

\section{THEORETICAL AND EMPIRAICAL LITERATURE REVIEW}

The traditionalist view on the impact of trade currency depreciation indicates that it leads to an expansion in trade via lower export prices. On the other hand, the structuralist school stresses some contractionary effects (Meade 1951). Hirschman (1949) points out that currency depreciation from an initial trade deficit reduces real national income and may lead to a fall in aggregate demand. Kandil and Mirzaie (2002) argued that currency depreciation gives with one hand by lowering export prices and takes away with the other hand by raising import prices. They observed that if trade is in balance and terms of trade remain unchanged, these price changes offset each other, especially when the famous Marshall-Lernercondition is not satisfied. If imports exceed exports, the end result is a reduction in real income within a country (Cooper, 1971) ${ }^{2}$.

Recently, it is a widely accepted belief that chronic misalignment in the real exchange rate has been a major source of slow growth in Africa and Latin American countries while prudent macroeconomic trade and exchange rate policies have encouraged growth in Asia (Edwards, 1988) ${ }^{3}$. According to Yotopoulos and Sawada (2005), systematic deviations of nominal exchange rate (NER) from their purchasing power parity (PPP) levels may engender serious instabilities of the international macroeconomic system. According to Baldwin, Skudelny and Taglioni (2005), disequilibrium exchange rate values have been conclusively shown to have negative link with trade $^{4}$. Some authors, however, argue that under the existence of forward exchange markets, exchange rate uncertainty can be completely covered so that there is no impact of exchange rate uncertainty on trade (Ethier, 1973 and Baron, 1976). However, Viaene and de Vries (1992) argued that even under the forward exchange markets, there may be an indirect effect of exchange rate volatility on trade if hedging is costly.

\footnotetext{
${ }^{1}$ Also see Soludo and Adenikinju (1997), Agu (2002), Omotosho and Wambai (2005), Obaseki (2001), CBN (2007a), CBN (2007b), CBN (2008).

${ }^{2}$ Also see Diaz-Alejandro (1984), Krugman and Taylor (1978) and Edward (1986).

3 Also see World Bank, 1984 ; Ghura and Grennes, 1993; Rodrik, 1994 and Yotopoulos 1996

${ }^{4}$ Also see inter alia, European Commission, 1995
} 
Some past empirical studies have applied time series analysis and found no significant relationship between volatility and trade. The few that found a link suggest that the effect was very small ${ }^{5}$. Meese and Rogoff (1983), in a work which predates the co-integration literature, forecast exchange rates by simply regressing the exchange rate on the macroeconomic fundamentals and then using these parameter estimates, and the ex post realized and revised values of the future economic fundamentals to predict the future exchange rate. Cross-sectional studies carried out by Hooper and Kohlhagen (1978), De Grauwe (1987), Brada and Méndez (1988), De Grauwe and Verfaille (1988), Savvides (1992), Sapir, Sekkat and Weber (1994) and Eichengreen and Irwin (1995) found evidence of a negative effect of exchange rate uncertainty on export. Again, this effect, in most cases, was relatively small.

Some studies employed co-integration analysis such as studies conducted by Koray and Lastrapes (1989), Arize (1997, 1998a and b), Fountas and Aristotelous (1999) and Flam and Jansson (2000). A detailed empirical review of this strand of literature is reported in Baldwin, Skudenly and Taglioni (2005). The results of the studies with consideration of the time-series trend characteristics appeared to be more clear-cut and tended to suggest a significant negative effect of exchange rate uncertainty on the trade variables. For instance, Fountas and Aristotelous (1999) found a significant negative long-run effect of exchange rate uncertainty on trade. Wei (1999) found a negative and statistically significant effect for foreign exchange rate volatility on exports regarding future and optional instruments to hedge risk. Recently, Baum et al (2004) showed evidence of a positive relationship between exchange rate volatility and trade using a Poisson flexible lag structure, while Klaassen (2004) did not find evidence of any significant effect of exchange rate volatility on trade for G7 economies. Another study is Caporale and Doroodian (1994), who used a generalized autoregressive conditional heteroskedasticity $(\mathrm{GARCH})$ technique to measure the volatility of exchange rate and discovered significant negative effect of volatility on import trade. McKenzie and Brooks (1997) and McKenzie (1999) used ARCH modeling and introduced an exchange rate volatility term into their export trade models for both German-US and Australian trade flows respectively. Their results were statistically significant, but showed positive impact of volatility on trade, while the results were mixed for McKenzie (1999).

According to Anderton and Skudelny (2001), better results were obtained from studies that employed panel estimation techniques. For example, Abrams (1980), Thursby and Thursby (1987), Dell'Ariccia (1998), Pugh, et al (1999) and Rose (1999), all found significant negative effect of the proxy for exchange rate uncertainty. In particular, while Dell'Ariccia (1998) found that the trade gains resulting from the elimination of exchange rate volatility would have been 10 percent. Anderson and Skudelny (2005) discovered that exchange rate volatility would decrease extra-euro area imports by around 10 percent. Another strand of empirical studies apply gravity- type trade model to assess the impact of exchange rate volatility on bilateral trade. Pugh, et al., (1999) studied 16 OECD countries and showed that volatility leads to a permanent decrease in the level of trade by around 8 percent. Rose (2000) estimated a gravity trade model for 186 countries using a 5 -year moving average of the variance of the nominal exchange rate return and discovered that exchange rate volatility has a significant negative impact on trade (estimates showed that zero exchange rate volatility would have resulted in a 13 percent increase in trade). The Rose (2000) seminal work debated that countries participating in a currency union seemed to trade three times more than

\footnotetext{
${ }^{5}$ Also see Khan (1974), Koray and Lastrapes (1989); Belanger and Gutierrez (1998); Bini-Smaghi (1991); Kenen and Rodrik (1986) and Sekkat (1998).
} 
expected even when one controls for the impact of exchange rate volatility. This discovery was named the Rose effect. Rose and Engel (2002) and Glick and Rose (2002) found empirical evidence in support of the Rose effect. Furthermore, Aliyu (2007a) utilizes a gravitational model for NigeriaIndia bilateral trade and discovered that the exchange rate coefficient is theoretically consistent and statistically significant in the import model for the Indian economy but not for the Nigerian economy.

A number of empirical studies on Nigeria were carried out by Ojo, et al. (1978), Osagie (1985), which downplayed the role of exchange rate in the import-export trade in the country. This was largely possible in view of the system of exchange rate regime prior to the introduction of structural adjustment program in Nigeria in July 1986. However, Oyejide (1986), Omolola (1992), and Akanji (1992) discovered that exchange rate depreciation caused significant changes in the structure and volume of Nigeria's agricultural exports. Egwaikhide (1999), in his dynamic specification model of import determinants in Nigeria from 1953 to 1989, discovered that short run changes in the availability of foreign exchange earnings, relative prices, and real output (income) significantly explained the growth of total imports in Nigeria. On exchange rate instability, Nnanna (2002) links exchange rate instability in Nigeria to adverse monetary policy outcome, inflation, interest rate, and growth in money supply; and the failure of monetary policy was linked to fiscal dominance in the economy. Aliyu (2007b) showed that exchange rate significantly affects imports more than exports due largely to the monocultural nature of Nigeria's exports and inexhaustible and multifarious nature of its importsAliyu (2009) assessed the impact of oil price shock and real exchange rate volatility on the real gross domestic product in Nigeria using quarterly data for the period 1986 to 2007. He adopted the Johansen Vector autoregressive analysis (VAR) based cointegration technique to investigate the reaction of real gross domestic product to longterm fluctuations in oil prices and real exchange rate volatility and short-term fluctuations in the Vector Error Correction Model (VECM). The result of the long-run fluctuations showed that increase in oil price directly impacted the exchange rate by appreciating it and also significantly impacted real GDP.

Theoretically, the volatility-trade link is ambiguous according to Baldwin, Skudelny and Taglioni (2005). Dornbusch (1993) observed that the effect of an appreciated exchange rate on trade would be to make production of tradable unprofitable and non-tradable goods more profitable. In other words, imports will be high, while exports will tend to be discouraged. Cottani, et al (1990) found that misalignment was strongly related to lower per capita GDP growth, low productivity, slow export growth, and slow agricultural growth. Loaza et al (2002) also found a negative relationship between overvaluation and growth, holding other macroeconomic variables constant.

It is evident from the above review that studies on the impact of exchange rate volatility on trade have no dominant approach. The choice of a methodology and expected outcomes depend on the economy, the nature of data and availability of data. Gala and Luccinda (2006) state that two main methods of approaching exchange rate misalignment problems are the Purchasing Power Parity (PPP) approach and fundamental analysis. The PPP approach is based on relative prices and considers high international price levels as proxy for exchange rate overvaluation for a given GDP per capita level. In contrast, Fundamental analysis considers economic fundamentals in modeling exchange rate misalignment. These include terms of trade (TOT), balance of payments (BOP) financing condition, fiscal policy stance (surplus or deficit spending), degree of openness (OPN), GDP per capita, etc. 
It has also been established in the literature that a drop-in exchange rate volatility can increase the volume of trade in two not mutually exclusive ways: producing more exports and increasing the number of firms that are engaged in exporting. It is this theorization that accounts for a negative volatility-trade link (Baldwin, et al. 2005). Generally, the transmission mechanism through which exchange rate volatility affects non-oil exports in Nigeria could be both from the supply and demand channels. The supply side effects are related to the fact that exchange rate volatility could affect input prices. This induces some producers to lower output and in the face of volatile exchange rate, makes the exports less competitive. Exchange rate volatility could also negatively impact consumer confidence in importing countries and thus lowers demand. It also adversely affects investment indirectly by increasing producers' cost. Based upon this theory, this paper seeks to assess the link between exchange rate and non-oil export trade performance in Nigeria.

\section{METHODOLOGY}

The above review shows that studies on the relationship between exchange rate and trade can be carried out using different methods and models, which can be grouped into the traditional and option model $^{6}$. The traditional model derived from Gonzaga and Terra (1997) assures that there is no perfect hedging and exporters are risk averse. In the option framework, the international market for the country's export sector is noncompetitive. In this model, there are costs associated with entering and/or exiting from the market; therefore, an increased volatility of the real exchange rate would make the option of entering or exiting from the market more valuable.

This means that more volatility of the real exchange rate would make export less responsive to variations in the real exchange rate level ${ }^{7}$. More recently, Gala and Lucida (2006) stated that two main methods of dealing with exchange rate misalignment are Purchasing Power Parity (PPP) approach and fundamental analysis. The PPP approach is based on relative prices and considers high international price levels as proxy for exchange rate overvaluation for a given GDP per capita level. In contrast, fundamental analysis considers economic fundamentals in modeling exchange rate misalignment. These include TOT, balance of payment (BOP) financing condition, fiscal policy stance (surplus or deficit spending), degree of openness (OPEN), GDP per capita, etc.

This paper adopts the model developed by Aliyu $(2008)^{8}$ with some modifications. He adopted a vector error correction methodology in analyzing the effect of exchange rate volatility on Nigeria's exports between 1986 (first quarter) and 2006 (fourth quarter). Total non-oil exports in Nigeria are assumed to follow a path dictated by fundamentals such as exchange rate volatility in Nigeria and the United States (Nigeria's trading partner) and Nigeria's terms of trade and index of openness. This study differs structurally from Aliyu's model in the choice of explanatory variables. The dollar is an international currency and does not have similar trade characteristics and implications as the Nigeria's Naira. We feel that the inclusion of its volatility as an explanatory variable is inappropriate. We also excluded terms of trade from our explanatory matrix since Nigerian export goods are mostly primary products whose export prices would not compare objectively with the import price of manufactured goods in Nigeria. Another hypothesized determinant in Aliyu's model

\footnotetext{
${ }^{6}$ Akpokodje (2000) classifies the models into two: the traditional models and the option framework model.

${ }^{7}$ This approach was developed by Dixit (1989)

${ }^{8}$ See Aliyu (2008) Exchange Rate Misalignmnet: An Application of Behavioural Equilibrium Exchange Rate (BEER) to Nigeria.
} 
is the index of openness which is measured by the sum of imports and exports divided by gross domestic product. Introducing this as an explanatory variable would mean regressing export on export. This is because the volume of non-oil export which happens to be the dependent variable is also being captured by index of openness, an explanatory variable in the model. Apart from exchange rate, we introduced a domestic price index as a second repressors, which is proxied by composite consumer price index. The introduction of this variable is expected to add some value to the older formulations in which demand for an export commodity is a function of its export price, a product of domestic price and exchange rate. We therefore consider this simple model:

Model Specification:

$$
\mathrm{NOIL}=\mathrm{F}(\mathrm{EXCH}, \mathrm{CPI})
$$

Where:

NOIL $=$ Volume of Non-oil export

$\mathrm{EXCH}=$ Exchange rate (Amount of Naira per dollar).

CPI $=$ Composite price index.

Expressing (1) in natural log-linear form:

$$
\operatorname{lnnoil}=\mathrm{ao}+\mathrm{a} 1 \ln \operatorname{exch}+\mathrm{a} 2 \operatorname{lncpi}+\mathrm{u}
$$

Where:

$\ln =\log$ of variable $\mathrm{a} 1$ and $\mathrm{a} 2=$ constants ao and $\mathrm{u}=$ autonomous component and error terms, respectively.

The paper employs the Johansen's co-integration analysis to identify the long-term relationships among the variables. Prior to estimating the co-integrated autoregressive model by Johansen's method, the stochastic properties of the data were checked. The first step is to test for stationarity of the data for each variable using the unit root test. This test enables us to determine the order of integration of the variables. (The order of integration is the number of times they have to be differenced to become stationary). Next, a co-integration test will be conducted to find out if any co-integrating relationship exists between non-oil export and the explanatory variables (exchange rate and consumer price index). Finally, an error correction model is specified and estimated to determine if any long-run relationship exists between the regressand and the regressors. Annual data on Non-oil export volume, normal exchange rate of the Naira and composite consumer price index, were obtained from various issues of Central Bank of Nigeria $(\mathrm{CBN})$ statistical bulletin and International Monetary Fund (IMF) data base in nominal terms from 1961 to 2010.

\section{Test for Stationarity}

A test for stationarity of the variables indicates that the variables are nonstationary. Therefore, a further test was conducted at 1st difference. Summaries of the Augmented Dickey Fuller (ADF) and Phillips Perron (PP) unit root test are contained in table 1 below. ADF test statistic indicates that non-oil and exchange rate are stationary at their first difference at one percent level of significance. Meanwhile, consumer price index showed stationarity at ten percent when evaluated with a constant; and nonstationarity when evaluated with a variable. However, the Phillips-Perron unit root test showed all the variables to be stationarity at one, five, and ten percent levels of 
significance respectively. Therefore, we conclude that the variables included in the model are stationary at their 1st difference. Hence, this study rejects the null hypothesis of unit root to assume a verdict of stationarity by at least one test.

Table 1: Unit Root Test Applied to Variables

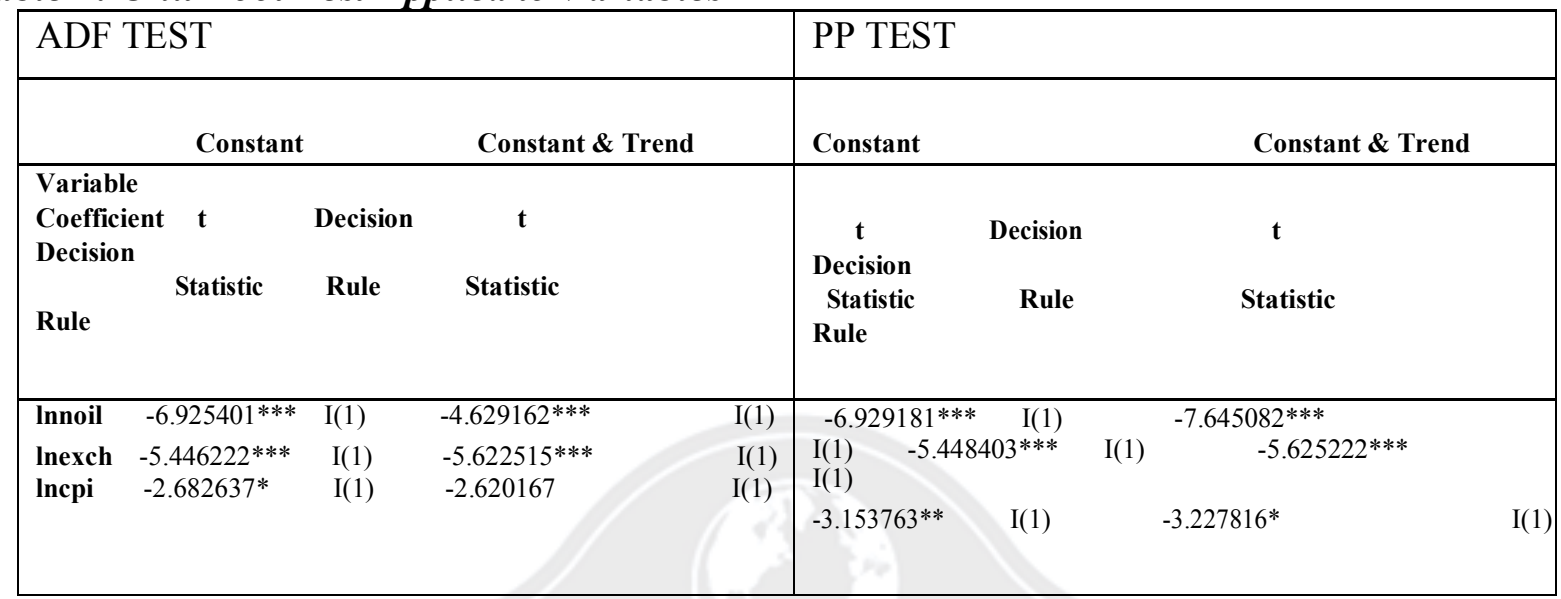

Source: Computed by Authors

Note: Three, Two and One asterisk denote rejection of the Null hypothesis of a unit root at 1\%, 5\% and $10 \%$ respectively based on MacKinnon critical values.

\section{Test for Co-integration}

The next step is to test for co-integration or long-term relationship between export volume and the explanatory variables. Table 2 presents the results of the tests for cointegration between non- oil export volume and the explanatory variables.

\section{Table 2: Co-integration analysis}

Johansen tests for co-integration

Trend: constant

Number of obs $=46$

Sample: 1965 - 2010

$$
\text { Lags }=4
$$

\begin{tabular}{lllll|c|c}
\multicolumn{2}{l}{$\begin{array}{l}\text { maximum } \\
\text { rank }\end{array}$} & parms & LL & eigenvalue & $\begin{array}{r}\text { trace } \\
\text { statistic }\end{array}$ & $\begin{array}{c}\text { critical } \\
\text { value }\end{array}$ \\
0 & 30 & 38.257147 &. & $21.9061 *$ & 29.68 \\
1 & 35 & 44.964801 & 0.25296 & 8.4908 & 15.41 \\
2 & 38 & 49.135434 & 0.16584 & 0.1495 & 3.76 \\
3 & 39 & 49.210193 & 0.00325 & &
\end{tabular}

\section{Source: Computed by Authors}

The co-integration result presented in table 2 above, shows that the null hypothesis of no cointegrating equation is cannot be rejected. The result reveals that the hypothesis of no cointegrating equation is accepted. The confirmation of no cointegrating equation means that: there exists no long run equilibrium relationship between non-oil export, the nominal exchange rate and 
domestic price of non-oil exports. The non-cointegrating result above validates the use of the error correction mechanism as adopted by this study to investigate the presence of a short-run relationship between the variables of interest.

\section{ERROR CORRECTION MODEL (ECM)}

The error correction mechanism (ECM) was first used by Sargan ${ }^{9}$ and later popularized by Engle and Granger corrects for equilibrium. An important theorem known as the Granger representation theorem states that if two variables $Y$ and $X$ are cointegrated, then the relationship between the two can be expressed as ECM. Since a co-integrating relationship is obtained among the variables in their first differences, rewriting equation (2) in their first differences is presented below:

Where:

$$
\text { dlnnoil }=b_{o}+b_{1} d \ln e x c h+b_{2} d \operatorname{lncpi}+u_{t}
$$

$$
\begin{aligned}
& d=\text { indicates first difference } \\
& u t=\text { white noise error term } \\
& b_{o}, b_{1} \text { and } b_{2}=\text { are coefficients }
\end{aligned}
$$

We now impose the lagged residual estimated from the cointegrating equation (3) above as an error correction term in an error correction equation:

Where:

$$
\text { dlnnoil }=\alpha_{0}+\alpha_{1} \text { dlnexch }+\alpha_{2} \text { dlIncpi }+\alpha_{3} U_{t-1}+e_{t}
$$

$$
\alpha_{0} \text { to } \alpha_{3} \text { are parameters. }
$$

The methodology employed in deriving the preferred short-run dynamic model is the general to

\begin{tabular}{|c|c|c|c|c|}
\hline Variable & Estimated Coefficient & Std. Error & t-ratio & p-value \\
\hline $\operatorname{dlnexch}(-1)$ & 0.37345 & 0.174297 & 2.1426 & $0.03939 * *$ \\
\hline dlnexch $(-3)$ & 0.896643 & 0.172473 & 5.1987 & $<0.00001 * * *$ \\
\hline dlnexch $(-4)$ & -0.492908 & 0.177529 & -2.7765 & $0.00887 * * *$ \\
\hline Dlncpi dlncpi (- & 0.564278 & 0.30792 & 1.8325 & $0.07564 *$ \\
\hline 2) dlncp1 $(-3)$ & -1.34305 & 0.380043 & -3.5339 & $0.00120 * * *$ \\
\hline dinnoul (-2) & 1.87575 & 0.37166 & 5.0469 & $0.00001 * * *$ \\
\hline \multirow[t]{2}{*}{ dlnnoil (-4) } & 0.246185 & 0.118595 & 2.0758 & $0.04554 * *$ \\
\hline & -0.308064 & 0.11147 & -2.7637 & $0.00916 * * *$ \\
\hline $\operatorname{ECM}(-1)$ & -0.345937 & 0.11002 & -3.1443 & $0.00345 * * *$ \\
\hline
\end{tabular}
specific approach. We start with a general error correction model, which includes lags up to the fourth order. This general model is then tested by using a priori expectations and statistical significance tests in order to arrive at a parsimonious preferred short-run dynamic specification. The parsimonious result for the model is presented in table 3 below.

Table 3: Non-oil Export Error Correction Model estimates

9 J.D. Sargan, "Wages and Price in the United Kingdom: A study in Econometric Methodology," in K. F. Wallis and D. F. Hendry, eds., Quantitative Economics and Econometric Analysis, Basil Blackwell, Oxford, U. K., 1984. 


$\begin{array}{lcccc} & -0.227104 & 0.127278 & -1.7843 & 0.08177 * \\ \text { R-squared } & & & \text { F statistics } & 7.224254 \\ \text { Adj R-squared } & 0.602006 & & \text { P-value (F) } & 8.74 \mathrm{e}-06 \\ \text { Durbin-Watson } & 0.508361 & & \end{array}$

Source: Computed by Authors

Note: $* * *, * *$ and $*$ implies statistically significant at $1 \%, 5 \%$ and $10 \%$ respectively.

From table 3, it is obvious that all the coefficients led to the expected a priori signs. In specific terms, table 3 indicates that current volume of non-oil export is determined by both current and accumulated values of exchange rate of the naira and the domestic prices of export goods. Since a long-run equilibrium exists between non-oil export and the explanatory variables, the coefficients represent steady state elasticities (see Iyoha. 1976) ${ }^{10}$.

Evidence from table 3 above shows that the R-squared value 0.60 signifies a high explanatory power of the regressors in the model. Furthermore, the adjusted R-squared for the model is 0.51 , indicating that at least 51 percent of variations of the value of Nigeria's non-oil export is explained by variations in exchange rate and domestic prices of exports. The 7.22 value of the F- statistics is significant enough to confirm the joint significance of the regressors when combined together. The Durbin-Watson statistic of 2.04 indicates the absence of auto-correlation in the model.

The first variable in the error correction model result indicates that a 100 percent increase in the amount of Naira that exchange for one US dollar will elicit 37 percent change in non-oil export volume for the next year, 90 percent increase in the third year, and a fall in volume by 49 percent in the fourth year. This finding shows that a sudden increase in the value of the exchange rate will almost result in a geometrical increase in the volume of non-oil exports within the first and third year. Therefore, we can say exchange rate of the naira no doubt exerts strong influence on the volume of non-oil export in Nigeria. This result finding is a confirmation of earlier studies carried out on Nigeria ${ }^{11}$. This is because most producers of non-oil exports are being encouraged to increase output with a depreciation of the naira to the dollar, which makes their goods cheaper in the international market. In other words, an increase in the exchange rate leads to increase in the international price of non-oil exports for Nigeria. This phenomenon is desirable by export suppliers as it means greater income on their output.

The next variable in the Error Correction result is the consumer price index. The ECM result demonstrates that domestic prices (proxied by CPI) have the capacity to boost export. The result indicates that a 100 percent increase in domestic price of a nonoil export commodity will increase its exports immediately by 56 percent in the current year and reduce the volume by 137 percent in two years if the increase is sustained before raising the volume in the third year by 188 percent. The reason is that a considerable percentage of the nation's non-oil exports is agricultural products. The producers of these goods are encouraged by higher prices to increase production which initially makes more of the products available for export. With the increase in price sustained at 100 percent,

\footnotetext{
${ }^{10}$ Iyoha, M.A.(1976): “Demand for International Reserves in Less developed Countries: A distributed Lag Specification", Review of Economics and Statistics, Harvard University Vol. Lviii N0.3 (August)

${ }^{11}$ See Oyejide (1986), Omolola (1992), Akanji (1992), Ihimodu (1993) Osuntogun, et al (1993), World Bank (1994), Aliyu (1994 \& 2001)
} 
consumers would choose to seek for import alternatives or substitutes to the product; thereby, resulting in a decrease in volume of the exportable product. This phenomenon has the tendency to boost the output of the product with government introducing trade policies for such product. This measure is gradually becoming a common strategy adopted by every Nigerian government since the 1990s. With the intention of boosting local supply and protecting local producers from unfavorable international competition, the country feels that it can produce in large exportable quantity rather than importing.

The final variable in the error correction model is the non-oil export. The result indicates that a 100 percent increase in non-oil export this year will elicit a 25 percent increase in the export of the same product next year. Thus, non-oil export has the capacity to sustain itself for just one year. This is understandable. Most Nigerian non-oil exports are primary products, which are perishable or have a very short durable period. This fact is proven by the negative coefficient for the second to the fourth lagged period of non-oil export in the error correction model in table 3 above.

Lastly, the error correction term displays the speed of adjustment to restore equilibrium in the dynamic model. In particular, the ECM coefficients show how quickly variables converge to equilibrium and the ECM coefficient is expected to have a negative sign: a value of -0.23 for the error correction coefficient. The value suggests that the error correction variable is rightly signed and significant at 10 percent level. The result is a confirmation that non-oil exports in Nigeria have an automatic adjustment mechanism. This signifies that any short run discrepancy which may offset the long-run and short run relationship established in this study, adjusts itself back to equilibrium within 4years and 3 months (If ECM coefficient is 0.23 , it means that $23 \%$ of the adjustment is achieved every year. Thus, the adjustment is completed in about 4years and 3 months).

\section{CONCLUSION AND RECOMMENDATIONS}

The purpose of this paper is to empirically investigate the impact of exchange rate and domestic price on export trade in Nigeria. After the literature review and findings of the study in the area, the paper aligns itself within the premise of the traditionalist view. Thereby, we conclude that non-oil export trade in Nigeria is predicated by currency depreciation via lower export prices. The introduction of domestic prices, alongside naira rate of exchange as major determinants of non-oil exports in Nigeria has the implication of showing that currency devaluation could be used to improve the balance of payment position of the country. Therefore, it is recommended that policy measures from the monetary authorities in the country that would stabilize the foreign exchange market and the exchange rate be implemented to improve the balance of payment position of the country.

Furthermore, the addition of an important variable of the literature on export determinants in Nigeria is the domestic price level. The domestic price level shows conformation with the theory of demand and supply. In theory, export price is the multiplication of domestic price by the exchange rate which implies that a rise in exchange rate and or domestic price will translate to a higher export price. A higher export price is expected with lower demand for Nigeria's non-oil products. Therefore, this study recommends caution on the part of government when adopting trade policies in order to ensure that Nigeria does not create an unfavorable balance of trade and terms of trade with other trading countries. 


\section{REFERENCES}

Agu, C. (2002) Real Exchange Rate Distortions and External Balance Position of Nigeria: Issues and Policy Options, Journal of African Finance and Economic Development, Institute of African-American Affairs, New York University, New York.

Aliyu, S. U. R. (2007b). "Import-Export Demand Functions and Balance of Payments Stability in Nigeria: A Co-integration and Error Correction Modeling, Submitted to Journal of Social and Management Sciences (JOSAMS).

Aliyu, S. U. R. (2008). "Exchange Rate Volatility and Export Trade in Nigeria: An empirical investigation" MPRA paper 13490, University Library of Munich Germany. (Revised Feb. 2009).

Anderton, R. and F. Skudelny, (2001) "Exchange Rate Volatility and Euro Area Imports" European Central Bank (ECB) Working Paper, no. 64.

Arize, Augustine C. (1998a) "The Effects of Exchange Rate Volatility on U.S. Imports: An Empirical Investigation" International Economic Journal, 12(3): pp. 31- 40.

Arize, Augustine C. (1998b) "The Long run Relationship between Imports Flows and Real Exchange Rate Volatility: The Experience of Eight European Economies", International Review of Economics and Finance, 7(4), pp. 417 - 435.

Baldwin, R., F. Skudelny and D. Taglioni (2005) "Trade Effect of the Euro: Evidence from Sectoral Data, European Central Bank Working Paper Series, (February) No. 446.

Baum, C. F., M. Caglayan, and N. Ozkan (2004), "Nonlinear Effects of Exchange Rate Volatility on the Volume of Bilateral Exports ", Journal of Applied Econometrics Vol. 19, pp.1-23.

Caporale, Tony and Khoswrow Doroodian (1994) "Exchange Rate Variability and the Flow of International Trade", Economics Letters, 46: 49 - 54.

Chang Fuzhi and Orden David (2005) "Exchange Misalignment and its Effects on Agricultural Producer Support Estimate: Empirical Evidence from India and China" International Food Policy Research Institute (IFPRI), MTID Discussion Paper, No. 81. Washington D.C.

Corrinne Ho and Robert N McCauley (2003) Living with Flexible Exchange Rates: Issues and Recent Experience in Inflation Targeting Emerging Market Economies, Monetary and Economic Department, BIS Working Papers, No 130

Cote, A. (1994) "Exchange Rate Volatility and Trade", Bank of Canada Working Paper, 94-5 Dell'Ariccia, G. (1998) Exchange Rate Fluctuations and Trade Flows: Evidence from the European Union. IMF Working Paper, WP/98/107.

Dixit, A. (1989) Hysteresis, Import Penetration, and Exchange Rate Pass-Through. Quarterly Journal of Economics, Vol. CIV, No.2 (May) 205-227.

Dornbush, R. and Frankel, J. (1988) "The Flexible Exchange Rate System: Experience and Alternatives" in S. Borner editions (ed.) International Finance and Trade, International Economic Association and MacMillan Press, London.

Dufrenot, G and E. B. Yehoue, (2005) Real Exchange Rate Misalignment: A Panel Cointegration and Common Factor Analysis, IMF Working Paper, WP/05/164.

Egwaikhide, F. O. (1999) 'Determinants of Imports in Nigeria: A dynamic Specification' African Economic Research Consortium, (AERC) Research Paper, No. 91.

Fountas, S. and K. Aristotelous (1999). "Has the European Monetary System led to more Exports? Evidence from four European Union Countries”, Economic Letters, 62: 357 - 63. 
Franke, G. (1991). "Exchange Rate Volatility and International Trading Strategy" Journal of International Money and Finance 10: 292-307

Gala Paulo and Claudio R. Lucinda (2006). Exchange Rate Misalignment and Growth: Old and New Econometric Evidence, Journal of Economic Literature.

Ghura, D. and T. J. Greenes (1993). "The Rea Exchange Rate and Macroeconomic Performance in Sub-Saharan Africa," Journal of Development Economics. 42: 155 - 174.

Glick, R and A. K.Rose, (2002). "Does a Currency Union Affect Trade? The Time Series Evidence" European Economic Review 46(6), 1125-1151.

Hooper, P. \& S. Kohlhagen, (1978). The Effect of Exchange Rate Uncertainty on the Prices and Volumes of International Trade. Journal of International Trade 8, pp 483-511

Ilimi, Atsushi (2006) Exchange Rate Misalignment: An Application of the Behavioral Equilibrium Exchange Rate (BEER) to Botswana, International Monetary Fund, $\mathrm{WP} / 06 / 140$

Kandil and Ida Mirzaie (2002) "Exchange Fluctuations and Disaggregated Economic Activity in the US: Theory and Evidence", Journal of International Money and Finance, No. 1 (February) pp. $1-31$.

Khan, M. S. (1974) 'Imports and Exports Demand in Developing Countries', IMF Staff Working Papers, Vol. 21, No. 3.

Klaassen, F. (2004) "Why is it so Difficult to Find an Effect of Exchange Rate Risk on Trade?" Journal of International Money and Finance, 23, pp. 817-839.

Koray, F. and Lastrapes, W. (1989) Real Exchange Rate Volatility and US Bilateral Trade: a VAR Approach, The Review of Economics and Statistics 71, pp. 708712.

Lastrapes, W. \& Koray, F., (1990). Exchange Rate Volatility and US Multilateral Trade Flows Journal of Macroeconomics 12, pp. 341-363.

MacDonald, R., and J. Nagayasu (1998) "On the Japanese Yen-U.S. Dollar Exchange Rate: A Structural Econometric Model Based on Real Interest Differentials," Journal of the Japanese and International Economies, Vol. 12 (March), pp. 75- 102.

Mathisen, J. (2003) "Estimation of the Equilibrium Real Exchange Rate for Malawi." IMF Working Paper, WP/03/104.

McKenzie, M. (1999) “The Impact of Exchange Rate Volatility on International Trade Flows”, Journal of Economic Surveys, 13(1): 71-106.

Nnanna, O. J. (2002) Monetary Policy and Exchange Rate Stability in Nigeria, Central Bank of Nigeria's Economic and Financial Review, Vol. 40, Number 3. pp. 1 - 22

Obaseki, P. J. (2001) “The Purchasing Power Parity (PPP) Measure of Naira's Equilibrium Exchange Rate", CBN Economic and Financial Review, Vol. 36, No. 1. Pp 1-21.

Osuntogun, A., C. C. Edordu and B. O. Oramah, (1993) "Promoting Nigeria's Non-Oil Exports: An Analysis of Some Strategic Issues", Final Report, African Economic Research Consortium (AERC), Nairobi, Kenya.

Oyejide, T. A. (1986) "The Effects of Trade and Exchange Rate Policies on Agriculture in Nigeria", Research Report 55, International Food Policy Research Institute, Washington D.C.

Pugh, G., Tyrrall, D. and Tarnawa, L. (1999) Exchange Rate Variability, International Trade and the Single Currency Debate: a Survey. Meeusen (ed.) Economic Policy in the European Union: Current Perspectives (Cheltenham, UK: Edward Elgar).

Rogoff, K. (1996) “The Purchasing Power Parity Puzzle” Journal of Economic Literature 34(2), pp. 647- 668 . 
Rose, A. (2000) "One Money, One Market: The Effect of Common Currencies on Trade". Economic Policy (30), April 2000, pages 7-33.

Shatz, H. and D. G. Tarr (2001) "Exchange Rate Overvaluation and Trade Protection: Lessons from Experience", in Drabek, Z. (Ed), Globalization under Threat: The Stability of Trade Policy and Multilateral Agreement, Edgar Elgar: Cheltenham, UK.

Sapir, A., K. Sekkat and A. Weber, (1994), "The Impact of Exchange-Rate Fluctuations on European Union Trade", CEPR Discussion Paper, 1041, November.

Skudelny, F. (2002) Exchange Rate Uncertainty and Trade: a Survey, in: Essays on the Economic Consequences of the European Monetary Union, Chapter 1, Proefschrift voorgedragen tot hetbehalen van de graad van Doctor in de Economische Wetenschappen, Katholieke Universiteit Leuven

Taglioni, D. (2002) Exchange rate volatility as a barrier to trade: new methodologies and recent evidence, Économie Internationale 89-90 (2001-2002)

Thursby, J. G. and M. C. Thursby, (1987) "Bilateral Trade Flows, the Linder Hypothesis and Exchange Rate Risk", Review of Economics and Statistics, 69: 488 - 495.

Viaene, J. M. and C. G. de Vries (1992) "International Trade and Exchange Rate Volatility", European Economic Review, 36: 1311 - 21.

Yotopoulos A. Pan and Sawada Yasuyuki (2005) "Exchange Rate Misalignment: A New Test of Lung-Run PPP Based on Cross-Country Data", CIRJE Discussion Paper, February. 